\title{
WYZWANIA NAUKOWE INFORMATYZACJI UCZELNI PUBLICZNEJ
}

\author{
JANUSZ ZAWIŁA-NIEDŹWIECKI ${ }^{1}$, AGNIESZKA KAMIŃSKA ${ }^{2}$, \\ JANUSZ STAŃCZAK ${ }^{3}$, ANDRZEJ ZAJKOWSKI ${ }^{4}$
}

\author{
Politechnika Warszawska \\ ${ }^{1}$ Wydział Zarządzania \\ e-mail: j.zawila-niedzwiecki@wz.pw.edu.pl \\ ${ }^{2}$ Biuro Rektora \\ e-mail: a.kaminska@rekt.pw.edu.pl \\ ${ }^{3}$ Centrum Informatyzacji \\ e-mail: janusz.stanczak@pw.edu.pl \\ ${ }^{4}$ Centrum Informatyzacji \\ e-mail: andrzej.zajkowski@pw.edu.pl
}

SŁOWA KLUCZOWE

STRESZCZENIE uczelnia publiczna, strategia informatyzacji, polityka informacyjna, zarządzanie projektami

Uczelnia publiczna jest podmiotem o szczególnej roli społecznej, funkcjonuje równocześnie w kontekście wielowiekowej tradycji akademickiej i uniwersyteckiej, jak i w ramach bieżących uwarunkowań podmiotów publicznych oraz na konkurencyjnych rynkach edukacyjnym, naukowym i doradczym. Powoduje to potrzebę poszukiwania modelu organizacyjno-funkcjonalnego odpowiedniego dla specyficznej korporacji, jaką jest taka uczelnia. Jest to nie tylko wyzwanie z zakresu praktyki zarządzania, ale i naukowe, dotyczące poszczególnych aspektów funkcjonowania organizacyjnego i zarządzania (Woźnicki, 2007). Celem artykułu jest przedstawienie koncepcji metodycznego podejścia do procesu informatyzacji uczelni publicznej oraz badań, które temu służą. Podjęto tylko te z tych wyzwań, które są związane z prowadzeniem polityki informacyjnej oraz systematyczną informatyzacją uczelni publicznej. Nie wyczerpuje to potencjału wyzwań naukowych nowego organizowania uczelni publicznych w Polsce i zarządzania nimi .

\section{Wprowadzenie}

W Politechnice Warszawskiej, wraz z początkiem kadencji rektorskiej 2012-2016, po blisko 30 latach prowadzenia wybiórczych prób informatyzacji uczelni, wprowadzono systematyczny program jej informatyzacji ${ }^{1}$. Określenie ,systematyczny” należy pojmować jako: zgodny ze

1 Strategia rozwoju Politechniki Warszawskiej, Strategia informatyzacji PW oraz Program informatyzacji PW są podane do publicznej wiadomości na stronie Centrum Informatyzacji PW www.ci.pw.edu.pl. 
strategią rozwoju (Iwankiewicz-Rak, Shulgina, 2013; Misja, wizja... 2009), odwołujący się do pryncypiów informatyzacji sfery publicznej oraz oparty na sięganiu po wzorce dobrych praktyk dotyczące kształtowania i wdrażania usług informatycznych (Zajkowski, Stańczak, 2015). Działaniom typu radykalna reorganizacja i scalenie odrębnych dotąd komórek odpowiedzialnych za różne grupy usług informatycznych towarzyszyły prace studialne i projektowe nad strategią informatyzacji. Obok bezpośredniego rezultatu, czyli tej strategii, doprowadziły one do zidentyfikowania problemów badawczych dotyczących specyficznej luki poznawczej, za jaką uznano brak jednoznacznie sformułowanych zasad funkcjonowania organizacyjnego i zarządczego dowolnej uczelni publicznej, która jest specyficzną korporacją. W niniejszym artykule scharakteryzowano tylko część tej luki, tę związaną z kwestią posługiwania się informacją oraz prowadzeniem procesu informatyzacji i kształtowania usług informatycznych. Poszczególne wyzwania zostały podjęte w formie dysertacji doktorskich, których koncepcje omówiono w punktach 3, 4 i 5. Natomiast uważny czytelnik, opierając się na charakterystyce determinant funkcjonowania uczelni publicznej, przedstawionej w punkcie 1, z pewnością zidentyfikuje jeszcze inne zagadnienia (wyzwania), także należące do tej luki.

\section{Determinanty funkcjonowania uczelni publicznej}

Instytucje szkolnictwa wyższego pełnią jedne z najważniejszych zadań w strukturze społecznej (Geryk, 2012), w tym kulturową rolę państwowotwórczą (Brzeziński, 1997; Węgleński, 2013). Ma to związek z procesem rozwoju społeczeństwa w aspekcie edukacji (Dworak, 2013) i uprawiania nauki oraz z procesem rozwoju gospodarki i poziomu życia społeczeństwa, czerpiącego z wiedzy akademickiej (du Valla, 2011). Wynika z tego szczególna pozycja społeczna uczelni i prestiż ich pracowników (Leja, 2013). Pośród ogółu uczelni te, które są uczelniami publicznymi, znajdują się w jeszcze bardziej specyficznej sytuacji. Po pierwsze, są podmiotami publicznym i w związku z tym podlegają wszystkim związanym z tym faktem obowiązkom, w tym obowiązkowi udostępniania informacji publicznych. Z niewielkim tylko uproszczeniem można uznać, że funkcjonalnie są urzędami. Po drugie zaś są uczestnikami konkurencyjnych rynków: edukacyjnego (Drapińska, 2011), naukowego (Dynek, 2011) oraz doradztwa (Ostrowski, 2013). W tym zakresie poddawane są oddziaływaniu mechanizmów typowych dla podmiotów biznesowych i stosownie do tego muszą kształtować swe rynkowe zachowania (Wawak, 2011). A jednocześnie, mimo że konkurują, to dużo łatwiej niż podmioty biznesowe wchodzą w relacje kooperencji (Sołek-Borowska, 2014), będącej od zawsze jakże budującą cechą integrującą środowisko akademickie.

\section{Strategia informatyzacji uczelni publicznej}

Strategia informatyzacji uczelni publicznej (dalej nazywana strategią) powinna być elementem strategii rozwoju uczelni. Jest opracowywana w kontekście uwarunkowań zewnętrznych w zakresie informatyzacji państwa oraz wewnętrznych założeń i potrzeb uczelni, przy uwzględnieniu najnowszych trendów świadczenia usług opartych na technikach informacyjnych, jak 
również już wdrażanych w uczelni rozwiązań (Zajkowski, 2016). Techniki informacyjne stanowią szybkozmienny obszar funkcjonowania uczelni, który ma kluczowy wpływ na jej funkcjonowanie i rozwój. Strategia powinna być podstawą działań dotyczących kierunkowych zmian w zakresie funkcjonowania uczelni z wykorzystaniem rozwiązań teleinformatycznych. Strategia obejmuje zagadnienia związane z obsługą:

- działalności statutowej w obszarach:

a) dydaktyki;

b) badań naukowych, innowacji i komercjalizacji wyników badań;

c) współpracy z otoczeniem;

- zarządzania uczelnią w obszarach:

a) administrowania zasobami;

b) ewidencji pracowników, studentów i doktorantów;

c) ewidencji projektów naukowych i badawczo-wdrożeniowych (Zajkowski, 2015).

Strategia ma na celu wskazanie kierunków zmian techniczno-organizacyjnych, które:

- umożliwią skuteczne osiągnięcie celów strategicznych i operacyjnych, zdefiniowanych w strategii rozwoju;

- umożliwią efektywne świadczenie usług teleinformatycznych oraz zracjonalizowanie poziomu ich kosztów;

- przyczynią się do uatrakcyjnienia uczelni pod względem technologicznym dla studentów $\mathrm{i}$ innych interesariuszy;

- określą mierniki osiągania celów, uwzględniając jakość usług i potrzeby interesariuszy z optymalizacją nakładów na rozwiązania teleinformatyczne;

- zapewnią skuteczne i niezawodne usługi teleinformatyczne przez konsolidację i standaryzację zasobów teleinformatycznych oraz centralizację zarządzania i finansowania w formie centrum usług wspólnych;

- zapewnią cykliczne weryfikowanie oraz dostosowywanie usług teleinformatycznych do zmieniających się potrzeb.

Strategia powinna być operacyjnie rozwijana w formie corocznych planów informatyzacji, których kluczowym zadaniem będzie doskonalenie usług, a w tym celu rozwiązywanie problemów wynikających z dotychczasowej organizacji świadczenia usług teleinformatycznych, takich jak:

- zbyt wysokie koszy utrzymania i rozwoju systemów teleinformatycznych w skali uczelni oraz ograniczona możliwość kontroli środków przeznaczanych na ten cel;

- ograniczenia w wymianie danych pomiędzy jednostkami organizacyjnymi i w dostępie do aktualnych danych;

- niekontrolowana redundancja danych;

- niedostateczna jakość świadczenia usług teleinformatycznych wynikająca z braku dojrzałej i nowoczesnej organizacji wsparcia tychże usług;

- brak jednoznacznego wyznaczania i spójnego stosowania standardów, zwłaszcza wobec braku zdefiniowania architektury korporacyjnej zasobów i usług teleinformatycznych; 
- powielanie funkcjonalności w różnych systemach;

- zróżnicowany, a czasami/często niewystarczający poziom bezpieczeństwa systemów teleinformatycznych, wynikający z braku jednorodnych i spójnych standardów bezpieczeństwa;

- ograniczona możliwość realizacji inicjatyw w zakresie usług teleinformatycznych o zasięgu wykraczającym poza ramy pojedynczej jednostki organizacyjnej uczelni.

W kontekście tak pojmowanych: strategii rozwoju oraz strategii informatyzacji, a zwłaszcza programu jej realizacji, należy interpretować wyzwania badawcze przedstawione w kolejnych punktach.

\section{Polityka informacyjna uczelni publicznej}

Związany z globalizacją wzrost konkurencyjności również wśród uczelni, potrzeby transparentności działań, wynikające z good governance, pożądany wzrost działań z obszaru social responsibility, problemy społecznego i gospodarczego zrównoważonego rozwoju, dynamika zmian technologicznych, jak również wyzwania dotyczące interesariuszy środowisk zewnętrznego i wewnętrznego uczelni wywołują potrzeby zmian komunikacji, którym uczelnie wyższe muszą sprostać. Ta wielowymiarowość i zarazem konieczność wpisywania bieżącej polityki informacyjnej uczelni w jej strategię rozwoju, a co się z tym łączy - w poprawę komunikacji uczelni $\mathrm{w}$ jej codziennych działań operacyjnych, jest wyzwaniem dysertabilnym na poziomie doktoratu, polegającym na zadaniu opracowania modelu polityki informacyjnej uczelni publicznej. Model ten, zapewniając optymalną praktykę informowania, powinien godzić cechy odpowiednie dla komunikacji masowej z uwzględnieniem tak elitarności akademickiej, jak i roli społecznej takiej uczelni. Warto zwrócić uwagę, że łaciński źródłosłów pojęcia komunikacja (comunicare), oznaczający dzielić coś z kimś lub uczestniczyć w pewnej zbiorowości, wskazuje tym samym cechę, którą model polityki informacyjnej powinien posiadać. Problematyka ta związana jest z optymalizacją procesów zarządczych, a bezpośrednią przesłanką do powstania dysertacji jest potrzeba usprawnienia wymienionych obszarów w kontekście organizacyjnego i operacyjnego kształtowania polityki informacyjnej i procesów komunikowania oraz zapewniania ich spójności z celami strategicznymi uczelni. Z dotychczasowych badań wynika, że:

- uczelnie publiczne rzadko stosują świadomie dobrane modele informacyjne, częściej zaś ich podejście jest spontanicznie (a więc słabo uświadomione), a wobec tego niekoniecznie spójne z deklarowaną przez nie misją, a wtedy także niekompatybilne z ich strategią rozwoju;

- modele polityki informacyjnej uczelni publicznych, jeżeli nawet są świadomie wprowadzone do użytku, to charakteryzują się zazwyczaj przypadkowym doborem narzędzi realizacji, przez co bywają również nadinformacyjne w negatywnym tego słowa rozumieniu;

- obowiązujące w uczelniach publicznych systemy sprawozdawcze, takie jak np. POL-on, będący zintegrowanym systemem informacji o szkolnictwie wyższym, wspierającym 
jednocześnie pracę MNiSW, nie są wykorzystywane do działań operacyjnych o charakterze komunikacyjnym;

- autonomia wydziałów, typowa dla uczelni publicznych, oraz stosowany mieszany model zarządzania w kontekście struktur organizacyjnych nie definiuje jasno nadzoru nad polityką informacyjną oraz przepływem informacji, który jest niejednorodny, niespójny i podatny na zakłócenia;

- tym samym kompetencje dotyczące hierarchii przekazywania informacji są ograniczone, zaniedbywane i nieprawidłowo umiejscowione organizacyjnie; częstokroć oparte na stereotypowo pojmowanej tradycji lub lokalnym zwyczaju;

- uczelnie publiczne, respektując wymogi prawne, opracowują polityki bezpieczeństwa informacji, jednak zapominają budować spójne z nimi plany komunikacyjne;

- istniejące modele rzadko uwzględniają aspekt społecznej odpowiedzialności uczelni, która nie jest właściwie rozumiana, przez co przeważnie kojarzona jest z dobroczynnością;

- zaniedbania w zakresie informatyzacji uczelni publicznych dodatkowo pogarszają jakość funkcjonowania polityki informacyjnej i funkcjonujących rozwiązań.

Sformułowano zatem problem badawczy jako: określenie determinant skuteczności, sprawności i efektywności polityki informacyjnej uczelni publicznej oraz zarządzania nią, zarówno w obszarze wymaganym przez prawo, jak również w obszarach komunikacji wewnętrznej i zewnętrznej oraz w obszarach budujących przewagę konkurencyjną i dotyczących marki oraz promocji. Zasadniczym celem pracy jest opracowanie modelu oraz zasad formułowania i praktykowania polityki informacyjnej uczelni publicznych. Cel ten jest realizowany przez podjęcie następujących celów szczegółowych:

- analiza stanu wiedzy dotyczącej istoty polityki informacyjnej organizacji,

- usystematyzowanie i scharakteryzowanie determinant prowadzenia polityki informacyjnej przez uczelnie publiczne,

- analiza praktyki, zalet, wad i skutków stosowanych podejść do prowadzenia polityki informacyjnej w wybranych uczelniach publicznych w Polsce,

- zaprojektowanie modelu polityki informacyjnej uczelni publicznej oraz modelu zarządzania tą polityką,

- sformułowanie zasad praktykowania polityki informacyjnej uczelni publicznej.

Realizacji celów służą pytania badawcze:

- Jaki jest stan wiedzy teoretycznej dotyczącej zagadnienia prowadzenia polityki informacyjnej przez organizację?

- W jakim stopniu polityka informacyjna organizacji powinna odpowiadać strategii rozwoju tej organizacji? Jakie czynniki na to wpływają i to zapewniają?

- Jakie są determinanty polityki informacyjnej w przypadku uczelni publicznej?

- Jaka powinna być struktura problemowa polityki informacyjnej uczelni publicznej?

- Jak powinno się zarządzać polityką informacyjną uczelni publicznej? 
Oczekiwanymi rezultatami będą (częściowo już ustalone i opublikowane):

- determinanty polityki informacyjnej uczelni publicznej w podziale na trzy grupy:

a) obowiązki prawne,

b) obowiązek moralno-wizerunkowy wyznaczany przez tradycyjną rolę społeczną,

c) wymogi rynku akademickiego,

- opis procesu formułowania i praktykowania tej polityki informacyjnej,

- zasady regulujące tę politykę informacyjną,

- całościowy model tej polityki informacyjnej (Kamińska, Zawiła-Niedźwiecki, 2013, 2014, 2015a, 2015b).

\section{Programowanie informatyzacji uczelni publicznej}

Projekty informatyzacji uczelni, jak wszelkie projekty informatyczne, wspierane są odpowiednimi podejściami zarządzania. Przede wszystkim wsparcia dostarczają metodyki zarządzania projektami. Po drugie, problem ujednolicania różnych aspektów budowania usług publicznych pozwala rozwiązać podejście architektury korporacyjnej, przy czym architektura korporacyjna państwa wskazuje jeszcze szerzej, jak formułować wymagania z punktu widzenia usług publicznych i ich interoperacyjności. Po trzecie, możliwe jest konsekwentne utrzymywanie tzw. ładu informatycznego przez korzystanie np. z metodyki COBIT, która definiuje różnicę między czynnościami nadzoru i zarządzania w aspekcie budowania usług informatycznych oraz wprowadza metodykę struktury ramowej nadzoru informatycznego. Także świadczenie usług informatycznych po wdrożeniu rozwiązania wspiera szereg sprawdzonych dobrych praktyk, zwłaszcza ITIL.

Dlaczego więc, mimo sprawdzonych podejść do budowania usług teleinformatycznych, wiele podmiotów publicznych odnotowuje niepowodzenia we wdrażaniu tychże usług? Dlaczego podobne problemy mają także uczelnie publiczne? Jedną z najczęstszych przyczyn porażek organizacji jest brak tzw. ładu organizacyjnego (,projectivity” lub „governance”), zwanego też dojrzałością projektową, oznaczającego powiązanie między wszystkimi obszarami działalności organizacji i spójne zarządzanie nimi. Potrzeby zmiany bardzo często są przesłaniane przez bieżące aktywności. Odsuwanie problemów na dalszy plan to powszechne zjawisko, dlatego istotne jest szukanie takiego sposobu łączenia różnych aspektów działania organizacji, żeby żaden z nich nie był ignorowany. Z jednej strony zachodzą bieżące operacje, a $\mathrm{z}$ drugiej strony jest miejsce na zmiany i rozwój.

Kolejną przyczyną niepowodzeń jest nieprawidłowy przydział ról. Dotyczy to zwłaszcza nadmiernego wtłaczania służb informatycznych w role pozainformatyczne, w tym tzw. właściciela merytorycznie kompetentnego w kwestiach organizacji i zarządzania usługami. Wobec tego kluczowa dla długoterminowej efektywności usług informatycznych jest organizacja służb informatycznych, ich umiejscowienie w strukturze i procesach uczelni oraz zasady współpracy z jednostkami, dla których budowane jest informatyczne wsparcie realizowanych przez nich procesów. Istnieje wyraźna luka polegająca na braku dostatecznych badań naukowych z zakresu 
zarządzania uczelniami oraz podmiotami publicznymi, w których podejmuje się kwestie: modelowania struktury organizacyjnej, ról i odpowiedzialności zarządzania uczelnią opartych na badaniu i modelowaniu procesów; zarządzania opracowywaniem (dobieraniem), wdrażaniem i eksploatacją systemów informatycznych; zarządzania świadczeniem usług teleinformatycznych; stosowania środowiskowych standardów dobrych praktyk. W szczególności przyjęta rola i miejsce służb teleinformatycznych w uczelni nie odpowiada nowoczesnym potrzebom społecznym, wynikającym z transformacji cyfrowej. Nie ma bowiem teoretycznych wzorców wspierających transformację uczelni jako specyficznej korporacji. W celu doskonalenia organizacji należy rozpatrywać jednocześnie dojrzałość procesową i dojrzałość zespołów realizujących te procesy. Błędem jest analizowanie tych kwestii rozłącznie lub koncentracja na jednej z nich.

Sformułowano zatem problem badawczy jako określenie modelowych zasad budowania oraz utrzymywania usług informacyjnych opartych na technologiach teleinformatycznych, które to zasady w przyjętej perspektywie czasowej zapewniają:

- metodyczny nadzór nad usługami teleinformatycznymi, z ustalonymi zasadami współpracy oraz integracji w ramach całej organizacji, $\mathrm{z}$ wykorzystaniem metod ciągłego doskonalenia świadczonych usług, zapewniających ich jakość, wspartych na wiedzy i zdolnościach wszystkich uczestników procesów;

- optymalizację procesów (wspieranych technologiami informatycznymi) w ramach całej organizacji;

- uwzględniają specyfikę (odrębności) poszczególnych jednostek organizacyjnych;

- korygowanie (ewolucję i adaptację) w procesie doskonalenia tych usług.

Zasadniczym celem pracy jest ustalenie, dedykowanej do specyfiki uczelni publicznej, metody takiego sterowania procesem informatyzacji jako części procesu rozwoju organizacji, aby był on zgodny ze strategią informatyzacji, która powinna stale pozostawać referencją dokonywanych rozstrzygnięć. Celem praktycznym jest zaproponowanie metody doboru metod i technik zarządzania pozwalających na efektywne budowanie usług wspierających realizację zadań uczelni publicznej opartych na technologiach informacyjnych. Cel ten jest realizowany przez podjęcie następujących celów szczegółowych:

- analiza organizacji usług teleinformatycznych w wybranych uczelniach publicznych, jednostkach administracji publicznej oraz podmiotach gospodarczych;

- identyfikacja i analiza: rekomendacji UE, prawa krajowego, metod i technik zarządzania procesami oraz usługami teleinformatycznymi, a także profesjonalnych dobrych praktyk, które mogą posłużyć transformacji uczelni i organizowaniu w niej usług informatycznych;

- studia literaturowe dotyczące: a) podejścia procesowego, b) kształtowania struktur organizacyjnych i kompetencji poszczególnych komórek organizacyjnych, c) architektury korporacyjnej w odniesieniu do programowania rozwoju informatycznego uczelni;

- charakterystyka determinant strategicznego uwarunkowania informatyzacji w uczelni publicznej; 
- opracowanie modelu zintegrowanego zarządzania usługami teleinformatycznymi w celu dostarczania oczekiwanych wartości w całym cyklu życia usług uczelnianych korzystających z technologii informacyjnych;

- opracowanie zasad racjonalizacji świadczenia usług teleinformatycznych w uczelni publicznej.

Oczekiwanymi rezultatami będą (częściowo już ustalone i opublikowane):

- model zintegrowanego zarządzania usługami teleinformatycznymi w uczelni publicznej;

- zasady racjonalizacji świadczenia usług teleinformatycznych w uczelni publicznej (Zajkowski, Stańczak, 2015; Zajkowski, 2015; 2016).

\section{Dedykowane metodylyi zarządzania projekttami progyramu informattyzacij uczelni publicznej}

Program informatyzacji i składające się nań poszczególne projekty, w szczególności wdrażania dużych systemów informatycznych, są trudne w realizacji ze względu na brak możliwości dostatecznie szczegółowego zdefiniowania z góry wszystkich wymagań, powodowany złożonością funkcjonalną, co przy późniejszej konfiguracji jest przyczyną wielostronnych sporów, w których uczestniczą: przyszli użytkownicy; doradcy, dostawcy, wykonawcy zewnętrzni oraz z reguły przedstawiciele uczelnianych ośrodków informatycznych. Spory te odpowiadają podstawowemu dylematowi, wobec którego staje uczelnia: czy potrzebne rozwiązanie (system) opracować samodzielnie we własnym ośrodku komputerowym, czy też zakupić produkt gotowy. Coraz częstsze są decyzje zgodne z najnowszymi trendami informatyzacji, tzn. sprowadzające się do wyboru rozwiązania uniwersalnego i jego dostosowania do specyfiki danej uczelni (do tej kategorii informatyzacji zalicza się konwencję outsourcingu i cloud-computingu). To dostosowanie jest współcześnie największym wyzwaniem, które powinno zostać rozwiązane przez ustalenie rekomendowanego toku postępowania w fazach: ustalania potrzeb, ustalania wymagań oraz wdrażania. Takie postępowanie przez podejścia wariantowe powinno uwzględniać także kwestie takie jak: rozmiar przedsięwzięcia, termin realizacji, zewnętrzne źródła finansowania, poziom tolerancji z zakresu tzw. magicznego trójkąta projektowego - zakres, czas, koszt. Takie uporządkowanie metodyczne, z zachowaniem niezbędnej elastyczności sprowadzającej się do antycypowanych wariantów, służy i skuteczności informatyzacji, i jej racjonalności finansowej. Tym samym przyspiesza osiąganie celów zgodnie ze strategią rozwoju.

Zasadniczym celem pracy jest opracowanie metodyki efektywnego zarządzania projektami programu informatyzacji uczelni publicznej. Główne aspekty, które zostaną podjęte, to:

- kreowanie postaw innowacyjnych wśród pracowników,

- szkolenia pod kątem korzyści z pracy zespołowej oraz z zasad pracy projektowej,

- klasyfikacja projektów realizacji strategii informatyzacji według nowo proponowanych kryteriów,

- zasady metodycznego podejścia do realizacji projektów strategii informatyzacji stosownie do ich klasyfikacji, 
- wprowadzenie dostosowań specyficznych dla uczelni publicznej w działaniach metodycznych w odniesieniu do uznanych metodyk zarządzania projektami, typu Prince2, PMBOK, Agile,

- działania zmniejszające negatywny wpływ autonomii wydziałów uczelni,

- działania zmniejszające negatywny wpływ użytkowników (osób fizycznych),

- uwzględnienie uwarunkowań formalnoprawnych podmiotów publicznych,

- działania zwiększające stopień przygotowania uczelni publicznej do realizacji projektu,

- działania mające na celu zwiększanie świadomości i czynnego poparcia władz uczelni dla realizowanych projektów informatyzacji oraz zwiększania roli służb informatycznych w uczelni.

Cel ten jest realizowany przez podjęcie następujących celów szczegółowych:

- analiza stanu informatyzacji i stopnia dojrzałości informatyzacji;

- opracowanie case studies wybranych projektów informatyzacji;

- analiza doświadczeń z realizacji programu informatyzacji;

- analiza możliwości podniesienia efektywności realizacji projektów informatycznych;

- analiza metodyk zarządzania projektami oraz wskazanie ich niedostatecznej adekwatności do specyfiki uczelni publicznej;

- opracowanie elementów metodycznego zarządzania projektami strategii informatyzacji specyficznych dla uczelni publicznej.

Realizacji celów służą pytania badawcze:

- Jakie są determinanty funkcjonowania uczelni publicznej jako specyficznej korporacji, w tym osiągania stanu dojrzałości informatyzacji?

- Jakie czynniki wpływają na skuteczność i efektywność wdrażania projektów informatyzacji?

- W jaki sposób poprawić skuteczność i efektywność realizacji projektów informatyzacji?

- Na czym polega nieadekwatność uznanych metodyk zarządzania projektami do specyfiki uczelni publicznej oraz jakie elementy doskonalące należy wprowadzić?

Oczekiwanymi rezultatami będą (częściowo już ustalone i opublikowane):

- wzorcowy podział projektów na kategorie uwzględniający po pierwsze: zakres, budżet i czas trwania, ale dodatkowo także pozostałe czynniki mające w środowisku uczelni publicznej na tyle duży wpływ na realizację projektów, że mogą pochłonąć dużą część budżetu, czasu, znacząco rozszerzać zakres;

- zasady wieloczynnikowego cechowania projektu, tj. definiowanie „wielkości projektu” (np. skala projektu i jego oddziaływania, wartość szacunkowa, czas trwania, zakres i złożoność) oraz istotnych jego cech (np. metodyka zarządzania, formuła realizacji, rozdzielność zamówień usług, źródło finansowania, pilność, krytyczność, autonomia użytkowników, stopień przygotowania zamawiającego itp.);

- podejście, które do każdej kategorii projektów przyporządkowuje czynniki, które mają największy wpływ na ich realizację; 
- na tej podstawie, w formie wykresów radarowych, zestawiane będą cechy projektów rzeczywistych w relacji do wzorcowych, w celu zwiększenia prawdopodobieństwa realizacji projektów w czasie, w budżecie i z określoną jakością (Stańczak, Zawiła-Niedźwiecki, 2015, 2016).

Podanie wyników w formie wykresu radarowego umożliwi: odniesienie zrealizowanych projektów do klasyfikacji wzorcowej; porównanie projektów między sobą z uwzględnieniem kolejności ich realizacji, aby każdy z nich konsumował doświadczenia wcześniejszych; wnioskowanie na tej podstawie dla opracowania wytycznych dedykowanej metodyki.

\section{Podsumowanie}

Przedstawione na początku artykułu przesłanki postrzegania uczelni publicznej jako korporacji o bardzo specyficznej naturze zostały wykorzystane do ustalenia luki badawczej, dla której wypełnienia sformułowano trzy problemy badawcze dla dysertacji doktorskich. Na pewno nie wyczerpują one jednak potencjału naukowego tej luki. Łatwo wyobrazić sobie na przykład, że kolejne problemy badawcze warto sformułować w odniesieniu do zarządzania zasobami materialnymi, zasobami ludzkimi, inwestycjami, bezpieczeństwem i cyberbezpieczeństwem laboratoriów badawczych, ochrony własności intelektualnej itd. Wskazując te przykłady, nie silimy się nawet na próbę wyczerpującej specyfikacji, bowiem potencjał naukowo jeszcze niezagospodarowany jest tu ogromny.

\section{Literatura}

Brzeziński, J. (1997). Trwałe wartości uniwersytetu. Forum Oświatowe, 1-2.

Dworak, J. (2013). Kapitał edukacyjny jako determinanta atrakcyjności szkoły wyższej. W: G. Nowaczyk, D. Sobolewski (red.), Marketing w szkole wyższej. Istota i znaczenie marki. Poznań: Wydawnictwo Wyższej Szkoły Bankowej.

Drapińska, A. (2011). Zarządzanie relacjami na rynku usług edukacyjnych szkół wyższych. Warszawa: PWN.

Dynek, K. (2011). Nauka i edukacja w uniwersytecie XXI wieku. Poznań: WSPiA.

Geryk, M. (2012). Społeczna odpowiedzialność uczelni. Warszawa: Oficyna Wydawnicza Szkoły Głównej Handlowej.

Iwankiewicz-Rak, B., Shulgina, L. (2013). Misja - marka - wizerunek uczelni - relacje wzajemne. W: G. Nowaczyk, D. Sobolewski (red.), Marketing $w$ szkole wyższej. Istota i znaczenie marki. Poznań: Wydawnictwo Wyższej Szkoły Bankowej.

Kamińska, A., Zawiła-Niedźwiecki, J. (2015a). Koncepcja modelu polityki informacyjnej uczelni publicznej w kontekście zrównoważonego zarządzania. Zeszyty Naukowe Małopolskiej Wyższej Szkoty Ekonomicznej w Tarnowie, vol. Prace z zakresu zarządzania, 1, 71-80.

Kamińska, A., Zawiła-Niedźwiecki, J. (2015b). Model procesu polityki informacyjnej uczelni publicznej. Przegląd Organizacji, 1, 23-29.

Kamińska, A., Zawiła-Niedźwiecki, J. (2014). Zasady polityki informacyjnej uczelni publicznej. W: I. Staniec (red.), Natura i uwarunkowania ryzyka (s. 329-337). Łódź: Wydawnictwo Politechniki Łódzkiej.

Kamińska, A., Zawiła-Niedźwiecki, J. (2013). Aksjologiczne podstawy projektowania strategii organizacji w koncepcji zrównoważonego zarządzania. W: L. Karczewski, H.A. Kretek (red.), Etyka biznesu i społeczna odpowiedzialność organizacji jako wyzwanie XXI wieku (s. 403-418). Opole: Wydawnictwo Politechniki Opolskiej. 
Leja, K. (2013). Doskonalenie relacji z interesariuszami jako wyraz społecznej odpowiedzialności uczelni. W: J. Woźnicki (red.), Misja i stużebność uniwersytetu w XXI wieku. Warszawa: Instytut Społeczeństwa Wiedzy, Fundacja Rektorów Polskich.

Misja, wizja i cele strategiczne szkolnictwa wyższego w Polsce w perspektywie 2020 roku (2009). Raport cząstkowy przygotowany przez konsorcjum: Ernst \& Young Business Advisory oraz Instytut Badań nad Gospodarką Rynkową. Warszawa.

Ostrowski, A. (2013). Uniwersytet jako przestrzeń konfliktu wiedzy i informacji. Przyczynek do analizy posttradycyjnego systemu eksperckiego. W: G. Nowaczyk, D. Sobolewski (red.), Marketing w szkole wyższej. Istota i znaczenie marki. Poznań: Wydawnictwo Wyższej Szkoły Bankowej.

Sołek-Borowska, C. (2014). Model kooperencji w sektorze edukacji wyższej - rozważania teoretyczne. W: A. Depta (red.), Wspótczesne problemy zarządzania a spoteczna odpowiedzialność biznesu. Łódź: Monografie PŁ, Wydawnictwa Politechniki Łódzkiej.

Stańczak, J., Zawiła-Niedźwiecki, J. (2016). Koncepcja metodyczna zarządzania projektami informatyzacji uczelni publicznej (artykuł zgłoszony na konferencję: „Twórczość - innowacyjność - przedsiębiorczość - technologie informacyjne w organizacjach" organizowaną przez Katedrę Informatyki Ekonomicznej oraz Katedrę Przedsiębiorczości i Zarządzania Innowacyjnego Wydziału Ekonomii Uniwersytetu Ekonomicznego w Katowicach, 17-19.11.2016 w Ustroniu).

Stańczak, J., Zawiła-Niedźwiecki, J. (2015). Czynniki sukcesu projektu wdrażania systemu SAP w Politechnice Warszawskiej. W: T. Porębska-Miąc (red.), Systemy wspomagania organizacji. SWO 2015 (s. 229-242). Katowice: Wydawnictwo Uniwersytetu Ekonomicznego w Katowicach.

du Valla, M. (red.). (2011). Raport końcowy „Modele zarządzania uczelniami w Polsce”. Kraków: Centrum Badań nad Szkolnictwem Wyższym Uniwersytetu Jagiellońskiego.

Wawak, T. (red.) (2011). Wyzwania jakości zarządzania w szkołach wyższych. Kraków: Wydawnictwo Uniwersytetu Jagiellońskiego.

Węgleński, P. (2013). Po co Polsce uniwersytet? W: J. Woźnicki, Misja i stużebność uniwersytetu w XXI wieku. Warszawa: ISW, Fundacja Rektorów Polskich.

Woźnicki, J. (2007). Uczelnie akademickie jako instytucje życia akademickiego. Warszawa: ISW, Fundacja Rektorów Polskich.

Zajkowski, A., Stańczak, J. (2015). The Challenges of Public University Informatization. Foundations of Management, 7 (1), 239-252.

Zajkowski, A. (2016). Strategia informatyzacji uczelni publicznej referencja utrzymania jakości ustug informatycznych (artykuł zgłoszony na III Ogólnopolską Konferencję Naukową „Rozwój i doskonalenie funkcjonowania organizacji” organizowaną przez Instytut Informacyjnych Systemów Zarządzania Wydziału Zarządzania Politechniki Częstochowskiej, 22.06.2016 w Częstochowie).

Zajkowski, A. (2015). Architektura korporacyjna jako element umiejscowienia IT w organizacji, na przykładzie strategii informatyzacji Politechniki Warszawskiej. W: W. Chmielarz, J. Kisielnicki, T. Parys (red.), Informatyka w spoleczeństwie informacyjnym. Warszawa: Wydawnictwo Uniwersytetu Warszawskiego. 


\section{RESEARCH CHALLENGES OF PUBLIC UNIVERSITIES}

COMPUTERISATION

KEYWORDS | public university, informatization strategy, information policy, project management

ABSTRACT The public university is a entity of a particular social role, functioning simultaneously in the context of the centuries-old tradition of academic and university, as well as under the current conditions of public entities and competitive markets, educational, scientific and advisory capacity. This results in the need to find a model of organizational and functional suitable for a specific corporation which is the university. This is not only a challenge in the field of management practices, but research concerning various aspects of the organization and management. The article only ones with these challenges, which are related to the conduct of information policy and systematic computerization of public university. However, this does not close the potential of the scientific challenges of the new organization and management of public universities in Poland. 